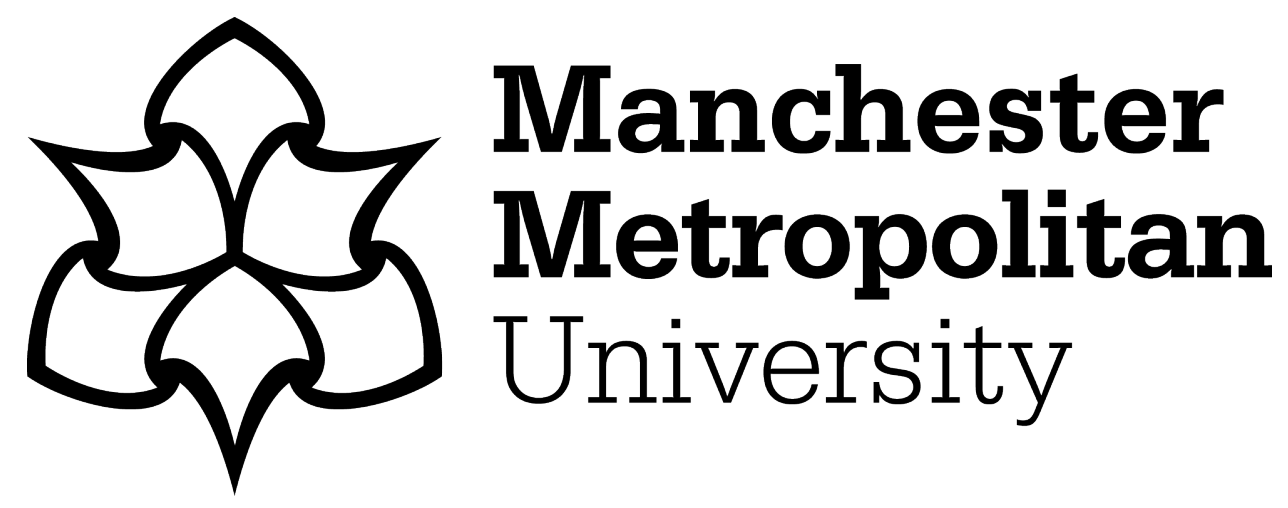

Skinner, H (2016) What's Occurring? Barry since Gavin \& Stacey. International Journal of Tourism Research, 18 (3). pp. 251-259. ISSN 1099-2340

Downloaded from: https://e-space.mmu.ac.uk/621391/

Version: Accepted Version

Publisher: Wiley

DOI: https://doi.org/10.1002/jtr.2001

Please cite the published version 


\title{
What's Occurring? Barry since Gavin \& Stacey
}

\author{
HEATHER SKINNER* \\ Green Corfu, Arillas, Corfu, Greece
}

\begin{abstract}
This paper presents the analysis of internet content relating to the UK family seaside resort of Barry that has been the key location setting of a popular television comedy series, which appears to be contributing positively to changing the town's destination image. While offering insights into the regeneration of UK seaside towns in particular through diversification into the creative and cultural industries, this study offers clues to the way destinations in general may draw together fragmented antenarratives from popular media representations, social media and the internet, and incorporate these when planning campaigns to affect the induced destination image. Copyright (C) 2014 John Wiley \& Sons, Ltd.
\end{abstract}

KEY WORDS UK seaside resorts; Barry Island; popular media; tourist-generated content; Gavin \& Stacey; antenarrative

This paper explores the way tourist destinations may better harness the positive effect of popular media representations on the destination's image. Research focuses on a specific instance of place portrayal in popular media by exploring perceptions of Barry since the airing of Gavin \& Stacey, a television comedy programme set in both Billericay in Essex and Barry in South Wales that appears to be contributing to Barry's changing image. This paper is not focusing on film or television tourism per se, but rather on the way a place's identity is portrayed through popular media, which in turn affects external perceptions of that place as a tourist destination.

\section{THE DECLINE AND REPOSITIONING OF THE UK SEASIDE RESORT}

Domestic tourism to UK seaside resorts has declined since the late 1970s with 'as many as 39 million visitor nights... lost at British seaside destinations from 1978 to 1988' (Agarwal, 1999:512), a decrease of around 27\% (Gale, 2005). This has been due to competition from relatively cheap, sunnier, overseas destinations; tourists seeking short breaks within Britain of alternative types to the traditional seaside holiday; and the unsuitability of outdated amenities and resort infrastructure (Gale, 2005). However, at least towards the end of the 1990s, 'despite the diminishing volume of holidays taken at the seaside, it is important to note that increased spending has to some degree compensated for this decline' (Agarwal, 1999:512). The UK situation compares with problems in 'many Mediterranean and Northern European coastal locations', although these foreign destinations face a lack of alternatives to tourism upon which to regenerate their economies (Agarwal, 1999:512).

*Correspondence to: Dr Heather Skinner, Vraganiotika, Corfu, Greece, GR490 80.

E-mail: heatherskinnercorfu@gmail.com
Despite the ongoing decline, there remains limited literature addressing the challenges facing traditional UK seaside resorts, and 'seaside towns remain the least understood of Britain's "problem" areas' (Rickey and Houghton, 2009:54), although these towns tend to share common problems, including:

disproportionate levels of worklessness...poor health; reliance on a declining tourist trade...low wage, low skill and sometimes seasonal employment sectors; an imbalance in seaside labour markets... a polarisation in the quality of local housing... [and a] peripheral location (Department for Communities and Local Government, 2010:8-9).

The decline in tourism is not spread evenly across the UK. A total of $75 \%$ of seaside tourism by volume and revenue had, for some time, been concentrated on eight resorts in England (Agarwal, 1999:512), whereas Wales' share of the overall UK seaside holiday market fell 'from $61 \%$ in 1991 to $41 \%$ in 2006' (WAG, 2008:4). The Welsh Assembly Government's Coastal Tourism Strategy (2008) therefore identified a need to address the specific problems that face seaside resorts in Wales.

Barry, the largest town in South Wales, is situated less than 10 miles from the Welsh capital city of Cardiff and is typical of a popular mass tourism UK seaside destination serving domestic tourists. Barry Island was the well-known home of a funfair that first opened in the 1890s and a Butlin's holiday camp that was open between 1966 and 1986. However, similar to many other UK seaside destinations, Barry has suffered a decline in tourist numbers and length of tourist stay. Although many such towns retain a higher proportion of local day-trippers than during their heyday, overall day-tripper numbers have also been in decline (Selby and Morgan, 1996). Barry's decline in popularity as a domestic holiday resort had been due to its "poor image and dilapidated environment [and] reputation for violence and drunkenness in the early 1980s'. Although many more recent visitors 'had noticed an improvement in the resort 
since their last visit', visitors 'still had an image of Barry Island being dirty and tatty' (Selby and Morgan, 1996:290-291). Interestingly, it was found that 'destination managers recognized the potential of including the town's "organic" images in their evaluation' of the $£ 2.5 \mathrm{~m}$ investment in the Barry Island Resort Action Programme (Selby and Morgan, 1996:287). More recent plans for improving the town since its designation as a Regeneration Area by the Welsh Government, attracting $£ 9 \mathrm{~m}$ of funding, recognize that 'the tourism sector in Barry, particularly given its location, is currently operating below its potential...Leisure facilities across Barry are in need of upgrading, and local events need to be encouraged, to increase civic pride and participation as well as attracting visitors' (Vale of Glamorgan, 2011:10).

According to Smith (2004:20), 'product enhancement and infrastructure improvement' revitalizes a seaside resort. Regeneration strategies 'through economic diversification' (Smith, 2004:20) can mean seaside towns ceasing to consider domestic tourism as the primary focus of their economic activity, instead focusing on, for example, the 'culturalcreativity sector', which can grow by 'taking advantage of the availability of cheap spaces to turn into galleries and workshops' and on conference trade, 'which would fit well with the accommodation infrastructure in seaside towns' (Rickey and Houghton, 2009:53). Strategies to attract domestic tourists focus more on reinvention (Smith, 2004), through 'renovating and refreshing public spaces, so that seaside towns tell a different story about themselves to new visitors' (Rickey and Houghton, 2009:52). However, stories about destinations are not told only by those responsible for promoting the place for tourism, and 'the creation and communication of a place's identity is...often outside of the control of the marketer' (Skinner, 2008:918).

\section{Destination image formation}

Destination image consists of two key components: cognitive/perceptive (beliefs and knowledge) and affective evaluations (feelings). For example, image can be the sum of beliefs, ideas and impressions that people have of a place or destination (Kotler et al., 1993), or an expression of knowledge, impressions, prejudice, imaginations and emotional thoughts an individual has of a specific object or place (Lawson and Baud-Bovy, 1977). A combination of both cognitive/perceptive and affective factors results in an overall positive or negative destination image.

The organic image of a destination is 'formed mainly as a result of exposure to non-tourist sources such as newspaper and other media reports, and the opinions of friends and family etc' (Greaves and Skinner, 2010:490). Potential visitors may also seek out promotional material from more formal sources such as tourist organizations to form an induced image (Gunn, 1988; Gartner, 1993) before a more complex image is formed as the result of an actual visit to the destination. This paper is primarily concerned with a destination's organic image and includes a consideration of the increasing importance of digital information and its effect on the image formation process.

\section{Place portrayal in popular media}

Although Morgan and Pritchard (1998) consider place representation in film and television as comparable with product placement, it would seem to be more appropriate to consider the portrayal of places in films and television as representing the genius loci, the sense or spirit of places as they are chosen to be portrayed (Skinner, 2011a). In this respect, the location itself is more than a mere placed product brand prop, an interpretation that is more useful when considering the way the representation of places in films and television can positively impact on destination image (Kim and Richardson, 2003) and lead to an increase in visitor numbers. Although some destinations have indeed 'leveraged the visibility that films provide', effective film tourism depends upon a range of factors including 'destination marketing activities, destination attributes, film-specific factors, film commission and government efforts, and location feasibility' (Hudson and Ritchie, 2006:388). There are also many examples of places whose identification as the location of popular TV series has boosted tourism, such as Bergerac's Jersey, where ' $40 \%$ of summer visitors and $30 \%$ of winter visitors reported being influenced by the television show,...the site of Castle Howard, featured in Brideshead Revisited, [where] visitor increases of $30 \%$ were witnessed' (Riley et al., 1998:923) and Heartbeat's Adensfield, set in Goathland in North Yorkshire, where 'the series has brought a phenomenal upsurge in visitor numbers...from 200,000 per annum, prior to 1991 , to around 1.2 million per annum once the programme achieved widespread popularity' (Mordue, 2009). The transmission of television programmes tends to be more geographically limited than that of films. Television programmes that are not distributed internationally will tend to attract more domestic tourists than films and television programmes with an international distribution that may reach a global audience and therefore attract a broader base of international tourists (Connell, 2005). Recognizing the influence of the media or organic image formation, 'Visit Britain has stated that $40 \%$ of overseas visitors to Britain come as a result of seeing Britain in a film or on a TV show' (Vale of Glamorgan, 2010:43).

\section{Gavin \& Stacey}

The television comedy series Gavin \& Stacey first aired on BBC 3 on 13 May 2007, moving via BBC 2 to BBC 1, running for a total of 20 episodes including Christmas Specials. Gavin \& Stacey attracted a viewing audience of 543000 for its first episode in 2007, rising to 10250000 for its final episode in 2010, with countless more people viewing the programme on DVD and on digital channel repeats. The Vale of Glamorgan's Draft Tourism Strategy (2010) 'recognises the marketing potential that TV programmes such as "Gavin and Stacey" has given Barry Island' (p32). 'Having a major film, series or TV feature filmed in the Vale of Glamorgan can help put the area on the map, build recognition and provide valuable publicity' (p43). However, the extent to which this television show has had an effect on the re-positioning of Barry as a domestic tourist destination has not yet been researched. 


\section{METHOD}

While tourism studies remain dominated by quantitative approaches, there have been recent calls for enquiry into places based more on narratives than on the more usual methods adopted by the social sciences (Skinner, 2011b). However, a narrative approach to studies in business and management tends to require a logical and linear sequence to telling these stories, achieving a coherent approach that develops the story's plot (Czarniawska, 2009; Gabriel, 2004). Thus, instead, as this research is relatively small-scale and exploratory, this paper will adopt the approach of antenarrative, which is more 'fragmented, non-linear, incoherent, collective and unplotted, and prenarrative speculations, a bet a proper narrative can be constituted' (Boje, 2001:1).

\section{Antenarrative is different from traditional narrative in two ways. First, antenarrative precedes narrative as a story can provide an account of an event or situation that possesses neither plot nor coherence ... Second, antenarrative is more speculative than narrative because it occurs in the flow of experience before narrative closure (Barge, 2004:108).}

Notable articles discuss the use of antenarrative when studying software failures in information systems (Dalcher and Drevin, 2003), the stories of those suffering chronic illness (Vickers, 2002) and the narratives of expatriates (Gardner, 2002). However, the value of antenarrative has been explored mainly in organizational discourse analysis. The organization's story is not usually told in the form of 'fully completed detailed texts to passive listeners', but, rather, 'storytelling becomes a collective enterprise where ... members contribute linguistic fragments' because 'a single unified coherent story that links organizational members together does not exist' (Barge, 2004:107). There will also be managers who, according to Barge (2004:109) 'need to weave their own and other stories together'.

In the story space relevant to this study, the virtual online world of news reports and tourist reviews, there are many story fragments to be found through primary investigation, but no single coherent narrative. This paper therefore adopts an antenarrative approach in order to explore the potential establishment of a more coherent narrative. A search for story fragments was undertaken in Google on 2 September 2012. The search parameters input into the advanced search tool were to find web links originating in the UK, written in English, containing all of the words 'Gavin', 'Stacey' and 'Barry' (rather than to 'Gavin \& Stacey' because the programme is also found in online references as Gavin and Stacey). This produced over 2500000 results. It was therefore necessary to focus the analysis only on search results that related to both the television programme and to tourism and perceptions of the town of Barry that had been provided through sources categorized as contributing to only organic destination image formation. Any content from sources attempting to induce tourism was excluded from the analysis. Two categories of data source remained: news reports (but not containing news about the television programme itself unless tourism was also mentioned) and sites that contained tourist-generated narrative content.

Of the 100 listed links in the first 10 pages of results returned in the Google search, 20 news reports were found that matched these criteria. Results linked to five online $B B C$ News reports: one story each from the online sites of newspapers the Express, Mail, Mirror, Metro, WalesOnlinethe online presence of Welsh newspapers the Western Mail, South Wales Echo, Wales on Sunday, eight from Celtic Weekly Newspapers and three from the local newspaper, the Barry and District News. Tourist-generated narrative content was found on the TripAdvisor site for the Gavin \& Stacey Tour, where seven posts from UK visitors relating to tourism issues in Barry were included in the analysis. User-generated content on this site was chosen only if it made reference to perceptions of the destination of Barry but was excluded if it made reference only to aspects of the running of the tour itself. User-generated content was also found on the TripAdvisor site for Whitmore Bay at Barry Island Traveller Reviews, where six posts about the destination were included in the analysis as these posts also made reference to the television programme. Content was excluded if it made reference only to perceptions of the destination of Barry and not to Gavin \& Stacey.

Although it is impossible to find agreement in the literature concerning what constitutes an appropriate sample size for a qualitative study, when considering number of data sources rather than number of individual participants, referring back to earlier work undertaken by Kuzel (1992), Onwuegbuzie and Leech (2007:116) acknowledge that '12-20 data sources generally are necessary', although 'in general the old rule seems to hold that you keep asking as long as you are getting different answers' (Baker and Edwards, 2012:3-4), after which it may be deemed that data saturation has been reached. Following the scrutiny of the 20 news reports and 13 posts that appeared in the top 100 internet-based search results returned using the relevant parameters, it was felt that that this sample size was adequate for an exploratory study of this nature and that data saturation had been reached.

Data were subjected to an intertextual analysis, proposed by Boje (2001) as one of the eight appropriate approaches to antenarrative analysis and which has been chosen in this case as this method embraces the multiplicity of voices and seeks out the manifest intertextuality (Fairclough, 1992:85) of the texts within texts found in the various story fragments to be analysed.

\section{Analysis}

News reports

Voices represented in the news reports included local traders affected by tourism to Barry and its Island resort, owners of houses and businesses used as locations for filming Gavin \& Stacey, councillors and other local politicians involved in defining and implementing strategic imperatives for the town, residents and tourists (Table 1).

Local town and county councils may recognize that tourism in Barry needs to be further supported, but rather than focusing on the negative aspects of the town as a 


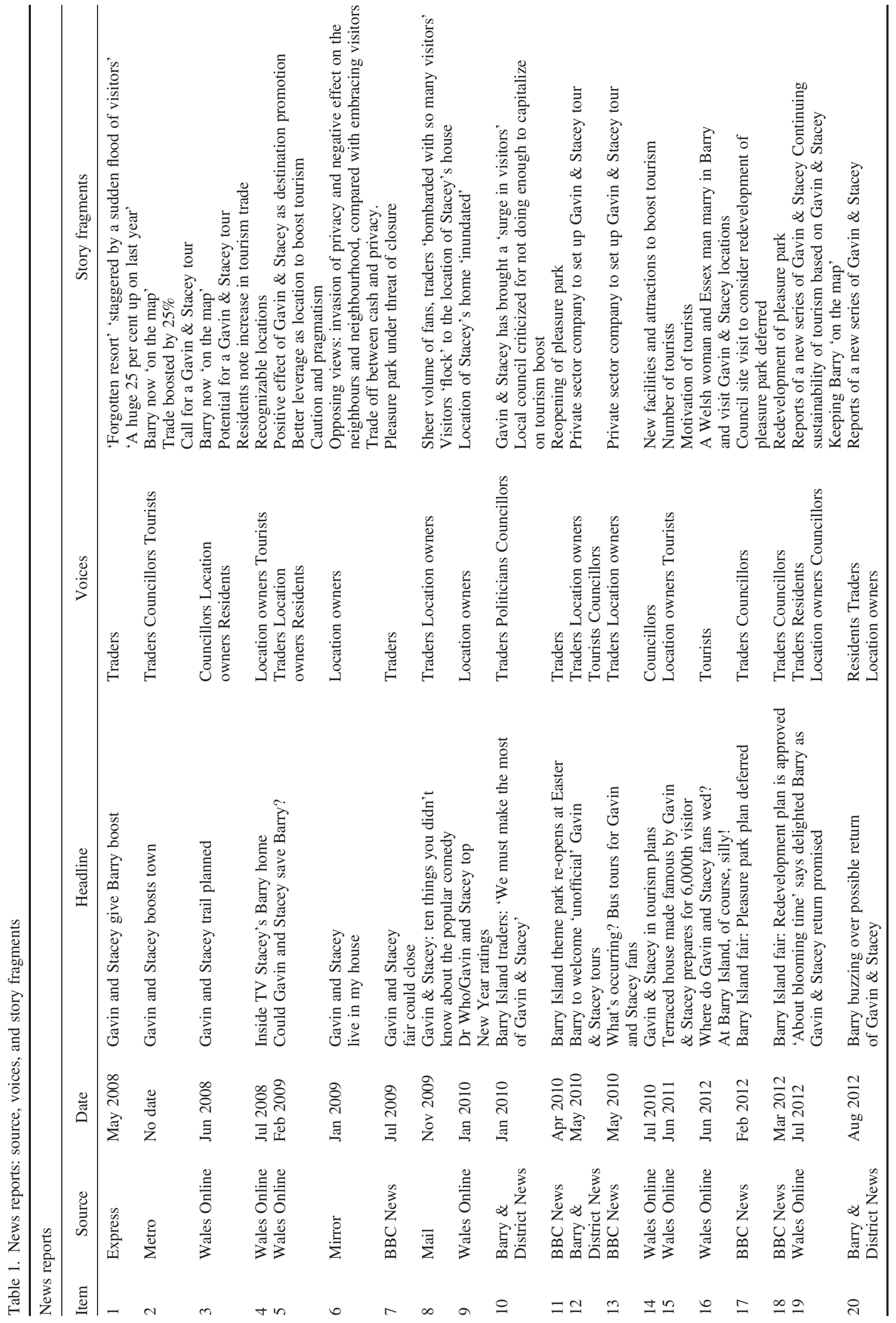


'forgotten resort' (Item 1), they should instead focus on the positive aspects of Gavin \& Stacey having put Barry back 'on the map' (Items 1, 2, 3 and 19). The notion that Barry Island is a 'forgotten resort' appears to resonate more with traders whose livelihoods are affected by any decline in the tourism trade. The owner of Marco's cafe, a location featured in a number of episodes of Gavin \& Stacey, 'has been in business on the Island for 35 years ... The only time I was a bit down was when the holiday camp closed. But things evolve and you have to move with the times' (Item 5). Both Marco and his brother, also a Barry Island trader, recognize the direct role that Gavin \& Stacey has had on providing the recent tourism boost to the town:

When I have talked to people there they know about Gavin and Stacey and say to me: 'Do you know how lucky you are? People would die for publicity like that' (Item 5).

This is also understood by the owner of the Barry Island Pleasure Park (Item 1), by the chairman of the Pride in Barry group, who commented once the series had ended that it would be fantastic if the show returned to our screens. It would be welcomed by traders who would welcome the cash it generates without a doubt' (Item 19), and by the owner of a Barry Island amusement arcade:

If it does happen it would give Barry Island a massive boost. It would rejuvenate everything that has gone on so far ... it's already had a dramatic impact on Barry Island (Item 20).

The council would also welcome a further series being created (Item 19). 'A happy spokesman at the local tourism office said: "There are a great many Gavin And Stacey fans in Barry and we are proud to have the town featured in such a popular television series"' (Item 1). Local councillors also appear keen for a themed tour of landmarks featured in Gavin \& Stacey to be set up for visitors (Items 2 and 3). 'I have also asked the committee to investigate other opportunities open to the council to benefit from the success of the show' (Item 3).

The voice of the owner of the house used as Stacey's Barry home appears in many story fragments. Her story is particularly interesting to trace how visitor numbers to the town have increased as a direct result of Gavin \& Stacey. 'I've now had 349 people coming to my house since the Christmas special last year' (Item 9). Item 12 reported 'more than 850 visitors ... since the series began'. Once a Gavin \& Stacey tour was established in 2010, visitor numbers increased significantly. 'I keep a visitors books ... and so far 5,981 people have signed' (Item 15). By July 2012 (Item 19), this figure had risen to '8,700 Gavin and Stacey fans' who had decided to 'visit the house and they are still coming'. This home owner has become a minor celebrity as a result of her association with the programme (Item 19). Unsurprisingly, she would also welcome the creation of a new series of Gavin \& Stacey (Item 20).

Residents' stories welcome formal efforts for the town to capitalize on the TV programme's success. A customer interviewed at Marco's cafe stated: 'my 10-year-old daughter Lauren likes it a lot. Developing Gavin and Stacey themes here would be appreciated by people like her' (Item 5). Other Barry residents agree:

The days when we had many tourists visiting Butlins are long gone ... Setting up a town trail based on the show would bring a lot of people in (Item 3).

The seaside part of the town has declined over the years. This would provide a much need injection of tourism (Item 3).

Tourists' story fragments also appeared in news reports such as one from May 2010:

The start of the tours next month comes after an Ask Jeeves survey revealed three per cent of all adults have searched for 'Barry in Wales' after watching Gavin and Stacey, increasing to eight per cent of those aged 16-29 (Item 12).

Prior to the tour being established in June 2010, tourists had created their own 'DIY tours' of locations from the series. One visitor expressed that following a visit to the location of Stacey's Barry home, her daughter is 'now the envy of all her friends' (Item 4). Another fan of the TV series 'who ran 210 miles from Billericay to Barry to raise money for charity ... "had to visit the house, which is an important part of the show" (Item 15). Item 16 reports that a Welsh bride and Essex groom held their wedding reception 'at the comedy show's featured chip shop ... Then they all played bingo and games at Island Leisure.' A council tourism and marketing officer also commented that 'a wedding party from Essex ... had to visit Barry Island to be able tell all their friends and fans of the show back in Essex that they had been there' (Item 2).

Association of the town with the TV series drew out the voice of past tourists to Barry. One news report elicited a comment from a reader from Liverpool:

the other day I saw a photo of the cast taken on the beach in a spot near to where we used to sit ... Ah happy memories (Item 8).

However, some story fragments indicate the trade-off that has to be made between increasing income and the challenges of TV induced tourism: 'The real-life arcade in Barry where Nessa works has been bombarded with so many visitors that bosses have put up a sign saying "Nessa is not working today"' (Item 8).

Moreover, an interesting narrative reflects the opposing worldviews of the two families of characters central to Gavin \& Stacey. The owner of the South Wales house portraying the Billericay home of Gavin is "ffed up with sightseers knocking on our door and asking us if they can have a look round ... It's an invasion of our privacy. And, what's worse, I'm embarrassed about the effect it has had on my neighbours"... Despite hating all the attention, Julia [the home owner] appeared on a BBC3 behind-the-scenes show ... She said: "It was a mistake on my part but I honestly believed it would put a stop to people being curious if they saw it on TV".' This home owner's view opposes that of the owner of the location of Stacey's home who earns 'a little 
extra cash. And she also gets to stay in "a nice hotel" when the cameras move in' (Item 6). 'Tourists flock to the three-bedroom house overlooking Barry Docks that is used as Stacey's mum's house in the series' (Item 8). In the voice of this homeowner: 'A lot of people are a bit too scared to knock at the door. But I make sure that I go out and invite them in' (Item 9).

Other story fragments display a more cautious viewpoint about the role Gavin \& Stacey can have on the town's fortunes.

The suggestion that a sitcom is going to be responsible for a miraculous turnaround in Barry Island's fortunes is clearly fanciful. But talk to anyone on the Island-traders, visitors, residents and councillors - and it soon becomes abundantly clear that the influence and legacy of the show will play a crucial role in its future (Item 5).

The boost in tourism to Barry due to Gavin \& Stacey has prompted calls for infrastructure and facilities improvements. Once again, the voice of cafe owner Marco is to be heard: 'We no longer have a cinema in the town. The site of the former holiday camp would be ideal for a cinema. We also need a hotel, and again part of that site would be perfect ... The traders here have banded together. We are united and committed to making Barry Island a success." That success may depend in part on Gavin and Stacey. But it will depend on much more than that, including the planned redevelopment of the Pleasure Park' (Item 5). The Pleasure Park has been experiencing difficulty in remaining a viable concern (Items 1 and 7). Although new operators were found to take over its running in 2010 'Poor weather conditions over recent summers had led to a drop in visitors ... and last year was forced to close during the summer because of bad weather. The owner of the pleasure park, Ian Rogers, has long-term plans to turn the land into a complex of restaurants and attractions' (Item 11). 'The planned redevelopment would see the 4.7 acre site turned into a mix of restaurants and cafes, a cinema, bowling alley and 124 flats'. This story fragment notes that a site visit planned by the council had been deferred (Item 17). However, by March 2012, the redevelopment plans were approved. 'The proposed indoor leisure/entertainment centre would form the primary commercial use and ... would serve as the hub of the development ... there is no longer a cinema in Barry and, therefore, it is considered that this element of the scheme would provide a valued facility that is unavailable anywhere else in the town' (Item 18).

The county council has faced much criticism for not capitalizing enough on the popularization of the town through the TV series. 'Barry Island has had a lot of reaction as a whole and there's been a knock-on effect for Barry, but as far as regeneration of Barry Island is concerned I think that's the last thing on their (the Council's) mind' (Item 10). Criticism was also levied at the council from a parliamentary candidate: 'It would be highly disappointing if the council failed to make the most of this'. The council's response stressed that the co-branding of anything related to the TV series had to be agreed with the production company Baby Cow (Item 10). Item 5 also noted that 'the production company is reluctant to move too quickly on such ideas, and tourism chiefs also want to ensure that any such developments are done properly'. In 2010, 5 years after Gavin \& Stacey first aired on digital channel BBC 3, the first tour of its Barry and district locations was established by a London-based tour company (Item 13). The tour company's director said that: 'In Barry they have been talking of a trail for ages, but nothing has come of it' (Item 12). Again, responding to claims of not doing enough to capitalize on the success of the TV show, a council representative 'has denied that the Vale has missed a tourism opportunity ... "We have worked closely with Baby Cow to develop a good working relationship and hope this will open up tourism opportunities of our own in the future which will be of additional benefit to the Vale" (Item 12). The council has also recognized the need to improve Barry's facilities and attractions in its new tourism strategy, which includes "the "aspiration" of establishing a museum. The strategy says: "We recognise the marketing potential that Gavin and Stacey has given Barry Island ... The vision of the Barry Regeneration Partnership Board is that Barry is once again a well known, high quality coastal destination"' (Item 14).

\section{Tourist-generated content}

Tourist-generated content was analysed from two sources, both of which were review pages on TripAdvisor. Comments have been attributed to posters on the basis of their location (if identified) and the date comments were posted.

There appears to be more positive perceptions of Barry as a contemporary tourist destination than found in Selby and Morgan's (1996) study, although not all reviewers stayed overnight in Barry itself, and some recommended visitors stay in the nearby capital city of Cardiff instead.

\section{Gavin \& Stacey tour site on TripAdvisor}

The majority of posts about Barry as a destination, and the experiences of those who had visited the town on the Gavin \& Stacey tour, were positive, with one notable exception. The tourist had undertaken the tour and found it disappointing.

did some really naff stops, including one at a pub which was a little rough ... Barry in general leaves alot to be desired, if you want to tour do it on your own! (London, 11 June 2012)

These voices also noted that the tour operates wider across the Vale of Glamorgan than the town of Barry itself to reach a range of locations from the series:

Apart from seeing many of the $G \& S$ locations you get to see a lot of the beautiful Vale of Glamorgan countryside (Stockport, 19 September 2011)

Never realised this was such a beautiful corner of Walesstunning scenery and enjoyed an afternoon on Barry Island beach after the tour (Kent, 28 August 2011)

However, even when the weather was poor, reviews posted on this site were still positive. 
The sights are brilliant. The typical Welsh rain didn't even ruin the day! (No specified location, 30 October 2011)

The tour started with Dave's Coach pulling up on a drizzly day in Barry ... We visited the church where the christening and the almost wedding took place. This was actually quite a bit further out of Barry than I thought ... Once you had got a drink from Marco's and taken in the views over Barry, it's on to the arcade... This was the perfect end to the tour as you are right in the middle of Barry and not far at all from the car park that the tour recommends for you ... If it's a nice day then it's worth it as Barry beach is really nice and well worth a day out! (Colchester, 15 April 2012)

Barry's proximity to Cardiff was also mentioned-but not necessarily positively, as this post identifies that the town's tourism infrastructure is not as developed as the neighbouring capital city:

I would recommend staying in Cardiff as Barry does not really have the best hotels. (Hinckley, 26 July 2011)

We drove all the way from Ayrshire to Barry and it was worth every mile of the drive. We stayed in Cardiff and Barry was only a short drive to get to ... This was our first trip to Wales and despite an unruly sat nav we have a great time (Kilmarnock, 25 April 2011)

Whitmore Bay at Barry Island: traveller reviews site on TripAdvisor

Some posts note that these tourists were attracted to visit Barry as a direct result of having viewed Gavin \& Stacey.

We wanted to visit the place where Gavin and Stacey was filmed ... The whole experience was great but we didnt spend more than an hour there. You would probably spend longer there if the weather was nice enough to go on the beach! (Bristol, 26 April 2012)

We went in to Barry ... Its such a nice friendly place. It's small, but has everything you need, very clean beach and toilets, plenty of eating places and a small fun fair. Thanks to all the locals for keeping it nice and being friendly. Lots of places to go and see nearby, so we will be going back (Liverpool, 16 July 2012)

Barry also attracts visitors who live locally.

We have just visited Barry Island Beach with our Grandson and what a great place to enjoy yourselves. The beach was very clean and with the sun out and the tide coming in we really enjoyed our day. We then went for drinks and Ice Cream at Marcos made famous by Gavin and Stacey. (Barry, 10 August 2012)

In the next story fragment, no specific trip has been reviewed, and this post is almost a promotion of the island resort.

Good old Barry island home of Gavin and Stacey, and those old enough to remember Butlins. Living close to the area, my family and I visit the bay almost every day. There's loads to do and see, for the young and old, and great places to eat! If you visit please try the Royal Cafe, it's near the arcades, the food is great and you can sit in, just a bit further down on towards the seafront there's a little burger place right on the end of the block near the gym park!! Omg the burgers are lush!! And one is never enough!! Come on make the trip, it's well worth a sunny day out. (No identified location, 12 April 2012)

Barry also attracts tourists who have fond memories of the resort from prior visits and who have since been prompted to visit following the airing of Gavin \& Stacey:

My previous visit was more than 15 years ago. I must say, I was more than pleased to see the resort is still as popular as ever with families and happy school groups enjoying a good old fashioned 'Fun' Day out at the seaside ... The Promenade area was clean with benches dotted along ... When I arrived the tide was in, but then the tide went out, the beach was as I remember it from my childhood-a large expanse of Sandy Beach full of people enjoying the usual seaside games, with lots of laughter. I really did enjoy my return visit. Although it was short. I will not leave it as long for my next visit (Maidenhead, 9 August 2011).

I have a soft spot for this place as my grown up lads all used to play here as kids, plus I used to watch Gavalar and Smiffy that was filmed here. Its only a little place with a little funfair and a few chippies and arcades, but it is the Welsh Riviera and the headlands further round away from the main front are beautiful, God I remember Barry Butlins thats some years ago. You would not be disappointed in any way tp spend a day in this superb little Welsh resort (Colne, 17 February 2012)

\section{DISCUSSION}

Overall results seem to present Barry in a positive light and not as 'dirty and tatty' as seen by respondents who reported in Selby and Morgan's (1996) case study, with very few story fragments referring back to the destination's heydey as a 1960 s to 1980 s UK seaside resort dominated by a Butlins holiday camp and funfair. Instead, visitors who may not have those memories appear to have 'discovered' Barry for the first time due to the airing of Gavin \& Stacey, and, having visited, seem to have formed complex images about the destination that have been overwhelmingly positive. Not only does this have the potential for repeat visit activity, but the user-generated content posted by these tourists can also positively affect the organic image of the destination in others.

Hudson and Ritchie (2006:388) stress that effective film tourism depends upon a range of factors including 'destination marketing activities, destination attributes, film-specific factors, film commission and government efforts, and 
location feasibility'. Yet in the case of Barry, the council itself, although recognizing the importance of activities designed to leverage television tourism, is not being particularly proactive, as exemplified with the location tour being established not by the council or by a local company, but instead by a London-based company who capitalized on the interest in tourists from London and particularly Essex (home to Gavin) to visit Barry (home to Stacey).

The results from this research do begin to offer clues that a narrative concerning the changing organic destination image of Barry may indeed be able to be constructed. It also points to concurrence with what Selby and Morgan (1996) found about destination managers' recognizing the potential of including a town's 'organic' images in their evaluations of capital investment towards regeneration. It would be imprudent to base a whole seaside town's regeneration efforts for domestic tourism on one coach tour of locations shown in one television programme airing 20 episodes over 3 years. However, it would be equally imprudent not to capitalize on the links with such a popular and successful show. It is often left to private sector organizations to actually do this, so it would seem sensible for multi-agency partnerships responsible for funding regeneration projects to ensure that a co-ordinated team approach at least can be facilitated, even if that means crossing county borders. In this case, it would seem sensible for Barry and Cardiff to capitalize not only on their proximity (with their centres being less than 10 miles apart) but also on the burgeoning film and television tourism opportunities offered by series such as Gavin \& Stacey and on other series filmed in the area that have international appeal and which could attract international as well as domestic tourists.

\section{CONCLUSION}

This paper offers two main contributions. First, contextualized against the background of the decline, and attempts at regeneration, of UK seaside resorts to offer clues to the way tourist destinations may better harness the positive effect of popular media representations. Second, to propose that the antenarrative approach adopted in this study not only offers a relevant theoretical contribution to studying tourist-generated content on social media sites, but also that such an approach could be usefully employed by those responsible for managing and marketing tourist destinations, to incorporate all of the various fragments of tourist generated stories that are posted on social media sites into a more coherent narrative about the destination and to co-ordinate this narrative in a way that communicates a more complete story about the destination.

The role of popular media, including film, television and web-based sources in contributing to the organic image of a tourist destination must not be underestimated. Instead, it should be understood and embraced by those responsible for marketing destinations, particularly those with outdated and/or negative images such as held about many of our seaside resorts. This approach can help complement planned regeneration and revitalization attempts led by local authorities, with strategies for facilitating a seaside resort's 'claim to fame' also included, with attendant commitment, conviction and funding, embracing the changes in organic image formation that have been brought through their place's portrayal in popular media.

\section{ACKNOWLEDGEMENT}

The author would like to acknowledge Brenda Tucker Lowell MITG, Blue Badge Guide for Wales and Gavin and Stacey Tour Guide, for her insights.

\section{REFERENCES}

Agarwal S. 1999. Restructuring and Local Economic Development: Implications for Seaside Resort Regeneration in Southwest Britain. Tourism Management 20(4): 511-522.

Baker SE, Edwards R. 2012. How many qualitative interviews is enough? National Center for Research Methods. [Internet] http://eprints.ncrm.ac.uk/2273/.

Barge JK. 2004. Antenarrative and Managerial Practice. Communication Studies. 55(1): 106-127

Boje D. 2001. Narrative Methods for Organization and Communication Research. Sage: London.

Connell J. 2005. Toddlers, Tourism and Tobermory: Destination Marketing Issues and Television-induced Tourism. Tourism Management 26(5): 763-776.

Czarniawska B 2009. The uses of narrative in social science research. In: Hardy MA, Bryman A (eds). Handbook of Data Analysis. Sage: London.

Dalcher D, Drevin L. 2003. Learning from information systems failures by using narrative and antenarrative methods. Proceedings of SAICSIT; 137-142.

Department for Communities and Local Government. 2010. Strategy for Seaside Success: Securing the Future of Seaside Economies. Department for Communities and Local Government: London.

Fairclough N 1992. Linguistic and Intertextual Analysis Within Discourse Analysis. Discourse Soc 3: 193-217.

Gabriel Y (ed) 2004. Myths, Stories, and Organizations: Premodern Narratives for our Times. Oxford University Press: Oxford.

Gale T. 2005. Modernism, Post-modernism and the Decline of British Seaside Resorts as Long Holiday Destinations: A Case Study of Rhyl, North Wales. Tourism Geographies. 7(1): 86-112.

Gardner C. 2002. An exploratory study of bureaucratic, heroic, chaos, postmodern and hybrid story typologies of the expatriate journey. Dissertation in Management. Department of College of Business Administration and Economics.

Gartner W. 1993. Image Formation Process. Journal of Travel and Tourism Marketing 2: 191-216.

Greaves N, Skinner H. 2010. The Importance of Destination Image Analysis to UK Rural Tourism. Marketing Intelligence and Planning 28(4): 486-507.

Gunn C, 1998. Vacationscape: Designing Tourist Regions, Bureau of Business Research, University of Texas, Austin, TX.

Hudson S, Ritchie JRB. 2006. Promoting Destinations via Film Tourism: An Empirical Identification of Supporting Marketing Initiatives. Journal of Travel Research 44: 387-396.

Kim H, Richardson SL. 2003. Motion Picture Impacts on Destination Images. Annals of Tourism Research 30(1): 216-37.

Kotler P, Haider DH, Rein I. 1993. Marketing places: attracting investment, industry and tourism to cities, states and nations. Free Press. 
Kuzel AJ. 1992. Sampling in qualitative inquiry. In: Crabtree BF, Miller WL (eds). Doing Qualitative Research: Research Methods for Primary Care. Vol. 3. Sage: Newbury Park, CA; 31-44.

Lawson F, Baud-Bovy M. 1977. Tourism and Recreational Development. Architectural Press: London.

Mordue T. 2009. Television, Tourism, and Rural Life. Journal of Travel Research 47(3): 332-345.

Morgan N, Pritchard A. 1998. Tourism Promotion and Power: Creating Images, Creating Identities. Chichester, UK: John Wiley \& Sons.

Onwuegbuzie A, Leech N. 2007. A Call for Qualitative Power Analysis. Quality and Quantity 41: 105-121.

Rickey B, Houghton J. 2009. Solving the Riddle of the Sands: Regenerating England's Seaside Towns. Journal of Urban Regeneration and Renewal 3(1): 46-55.

Riley R, Baker D, van Doren CS. 1998. Movie Induced Tourism. Annals of Tourism Research. 25(4): 919-935.

Selby M, Morgan NJ. 1996. Reconstruing Place Image: A Case Study of its Role in Destination Market Research. Tourism Management 17(4): 287-294.

Skinner H. 2008. The Emergence and Development of Place marketing's Confused Identity. Journal of Marketing Management 24(9/10): 915-928.

Skinner H. 2011a. In Search of the Genius Loci-the Essence of a Place Brand. The Marketing Review 11(3): 281-292.
Skinner H. 2011b. An archaeological excavation into the fields of place marketing and place branding. In Proceedings of the Academy of Marketing Conference 2011: Marketing Fields Forever, Patterson A, Oakes S (eds). Academy of Marketing: Liverpool.

Smith MK. 2004. Seeing a New Side to Seasides: Culturally Regenerating the English Seaside Town. International Journal of Tourism Research 6(1): 17-28.

TripAdvisor-Gavin \& Stacey tour site [Internet] http://www. tripadvisor.co.uk/Attraction_Review-g552070-d1933111-ReviewsGavin_and Stacey_Tour-Barry_Vale of Glamorgan_Southern Wales_Wales.html [Accessed 2 September 2012].

TripAdvisor-Whitmore Bay at Barry island: traveller reviews site [Internet] http://www.tripadvisor.co.uk/ShowUserReviews-g186468d2233535-r128658462-Whitmore_Bay_at_Barry_Island-Vale_of Glamorgan_Southern_Wales_Wales.html [Accessed 2 September 2012].

Vale of Glamorgan. 2010. Draft tourism strategy 2010-2015.

Vale of Glamorgan. 2011. Barry regeneration area themes and priorities: Barry regeneration area project development fund 2011-2012 appendix a.

Vickers MH. 2002. Illness, work and organization: postmodernism and antenarratives for the reinstatement of voice. Working paper, Unviersity of Western Sydney.

Welsh Assembly Government. 2008. Coastal Tourism Strategy. Welsh Assembly Government: Cardiff. 